\title{
Vojáci Skutečska 1914-1920
}

Barbora Novotná

\section{Soldiers of the Skuteč Region 1914-1920}

Abstract: Following article introduces the publication "Soldiers of the Skuteč county 1914-1920", which won the special award in a Museum publication category at XVIII. annual Gloria Musaealis Awards 2019. It is a probe into the operations of soldiers connected to Skuteč and its near precincts. The article is about the circumstances of the book's creation and its intention, which is primarily to pay respects to the participants in the war. It also describes the book's content and individual chapters. The life stories of the soldiers are put into the contemporary context and demonstrated on specific combat encounters. The main benefit is that the book brings testimonies of selected soldiers, the lists of legionnaires and registry of fallen and deceased soldiers as found in archives. The book provides interesting info and is a source of knowledge not only for regional historians but also as a valuable addition to the Czechoslovakian military history.

Keywords: Soldiers of the Skuteč, creation and description of the publication, legionnaires, Czechoslovak legions, the life stories of the soldiers, registry of fallen and deceased soldiers

\section{Ocenèná muzejní publikace vznikla s cílem vzdát úctu skutečským vojákưm}

Menší muzejní instituce typu městských muzeí nemají většinou pestré portfolio vlastní publikační činnosti. Někde chybí kapacity pracovní či personální, jinde finanční zázemí. Přesto se občas najde nadšení, které s podporou zřizovatele dokáže uskutečnit projekt, jenž je v dané oblasti nepřehlédnutelný. Takto můžeme označit i knihu Vojáci Skutečska 1914-1920, která byla vydána Městským muzeem ve Skutči, resp. jeho zřizovatelem městem Skuteč. Kniha byla přihlášena do XVIII. ročníku Národní soutěže muzeí Gloria musaealis, kterou vyhlašují společně Ministerstvo kultury ČR, Asociace muzeí a galerií a Český výbor ICOM. V kategorii muzejní publikace roku zaujala porotu natolik, že mezi 30 dalšími tituly získala "zvláštní oceněni".

Vzniku publikace předcházely dvě velké výstavy z let 2014 a 2018. Obě reagovaly na vlnu zvýšeného zájmu veřejnosti a médií o kulatá výročí první světové války. První výstava pod názvem Signum laudis aneb stř́pky ze zákopů a zázemí se zaměřila na přiblížení osudů vojáků $\mathrm{v}$ řadách rakousko-uherské armády, $\mathrm{k}$ jejichž zmapování bylo nutné provést obsáhlé rešerše $\mathrm{v}$ archivním fondu muzea a $\mathrm{v}$ místně príslušných archivech. $Z$ rozhovoru s iniciátorem publikace, ředitelem Městského muzea Skuteč, Liborem Akslerem (autor kapitol 6-11), vyplynulo, že tématika nebyla do té doby v muzeu nijak uceleně zpracována, a tak nebyla nouze o překvapivá zjištění. Před rokem 2018 pak proběhlo další dlouhodobé zkoumání archivní základny i původu a historie trojrozměrných sbírkových předmětů $\mathrm{v}$ muzejním depozitáŕi. Ve výsledku se objevilo mnoho nových dokladů o působení skutečských vojáků $\mathrm{v}$ řadách československých legií. Právě tuto skupinu podrobně představila druhá výstava Konec války - počátek republiky uskutečněná v roce 2018.

Na základě velkého zájmu veřejnosti o uvedené výstavy a následných četných dotazů směrem ke zpracovaným 


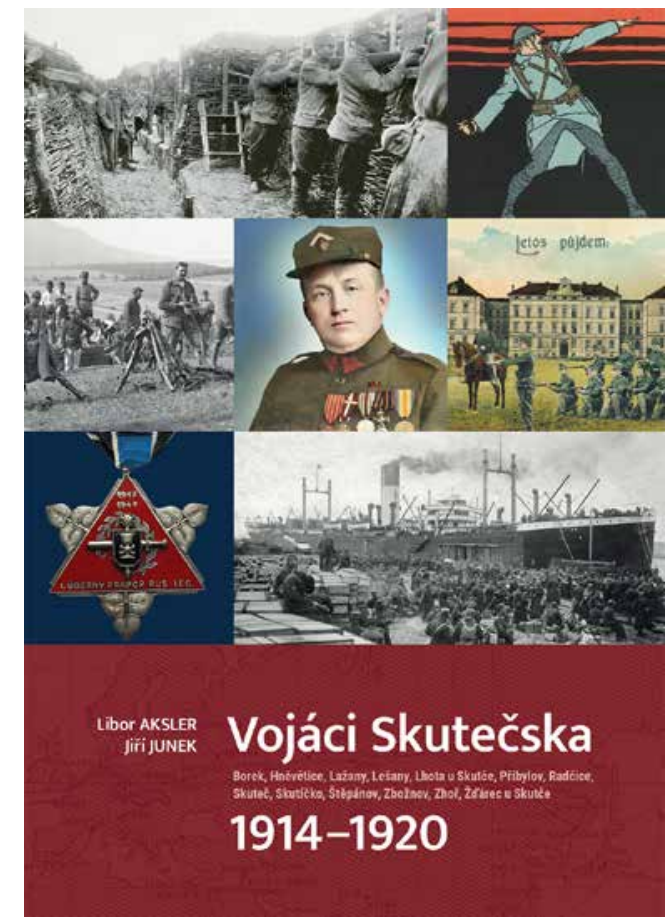

Obálka knihy

databázím vojáků a legionářu byla otevřena úvaha o možném publikování zjištěných dat. Postupně vykrystalizovala finální podoba knížky, která měla být trvalejší připomínkou a důstojnou vzpomínkou na válečnou anabázi vojáků pocházejících ze Skutče a jejích dnešních dvanácti místních částí. Právě tento rozsah se stal klíčovým pro stanovení, resp. omezení rozsahu pátrání i pro budoucí čtivost knihy. Celkem došlo ke zpracování osudů 202 padlých a zemřelých vojáků a 168 legionářu. Ačkoli se jedná o úzký vzorek na regionální úrovni, existují zde určité přesahy, jež umožňují čtenáři proniknout do každodenní válečné reality obecně prožívané našimi předky.

Velkou výhodou se pro možnost dohledání žijících příbuzných vojáků stala místní znalost obyvatel. Ti většinou se zájmem vyslechli zprávy o svém předkovi, jež muzeum dokázalo získat při svém pátrání, a na oplátku dohledali podobenky nebo jiné rodinné fotografie či dokumenty, nebo se podělili o historky, které se $\mathrm{v}$ rodinách o bývalé vojenské službě předků tradovaly. $\mathrm{V}$ případě potomků po legionárích se ukázalo, že mnozí s úctou uchovávají pradědečkův stejnokroj, deníky, trofejní šavle a jiné předměty $z$ doby jejich služby. Fotografie těchto artefaktů se pak staly vítaným doplněním textu.

Volba spoluautora $\mathrm{v}$ osobě ředitele Regionálního muzea ve Vysokém Mýtě se ukázala jako velmi štastná. Skutečské prostředí nebylo Mgr. Jiřímu Junkovi (autor kapitol 1-5) neznámé, protože před několika lety popsal jeho prvorepublikové období v Dějinách Skutče. Značnou devízou byl Junkův dlouhodobý zájem o vojenské dějiny se specializací na historii pluků z domovského posádkového města Vysokého Mýta, do kterého muži ze Skutečska rukovali.

\section{Popis knihy}

Celá kniha čítá 368 stran a je rozdělena do 11 kapitol a velkého množství subkapitol. Členění je přehledné s poznámkovým aparátem umístěným na dolních okrajích stránek. V závěru svazku jsou vysvětlivky použitých zkratek a znamének a také seznam vyobrazení dle jednotlivých kapitol s odkazem na zdroj či autora. Bohužel nedošlo ke vložení místního, věcného ani jmenného rejstř́íku. Prameny, zdroje a použitá literatura bývají povětšinou uváděny v poznámkách pod čarou, nebo na začátku kapitol, ale jejich souhrn na konci knihy by byl pro rychlý přehled žádoucí. K uspořádání rozsáhlých textů v prvních pěti kapitolách by se dle mého názoru hodilo rozdělit jejich obsah četnějšími podnadpisy. Je však třeba ocenit, že pokud to bylo možné, "narušila“ stránku textu alespoň vložená marginálie. Velmi vhodně byly dohledány a zařazeny fotografie, jež dobře graficky působí i v dalších oddílech knihy (zvláště v kapitolách 6 až 11 se seznamy nebo kratšími texty). Jednak dokumentují popisovaná fakta, jednak činí obsah pro čtenáře vizuálně přitažlivějším a ilustrativnějším.

Celkově je třeba pochválit grafickou úpravu, jež je výbornou vizitkou ateliéru 2123design s.r.o. Nešetřilo se zde na kvalitním tisku a na uživatelsky př́jemné speciální vazbě silné knihy umožňující 


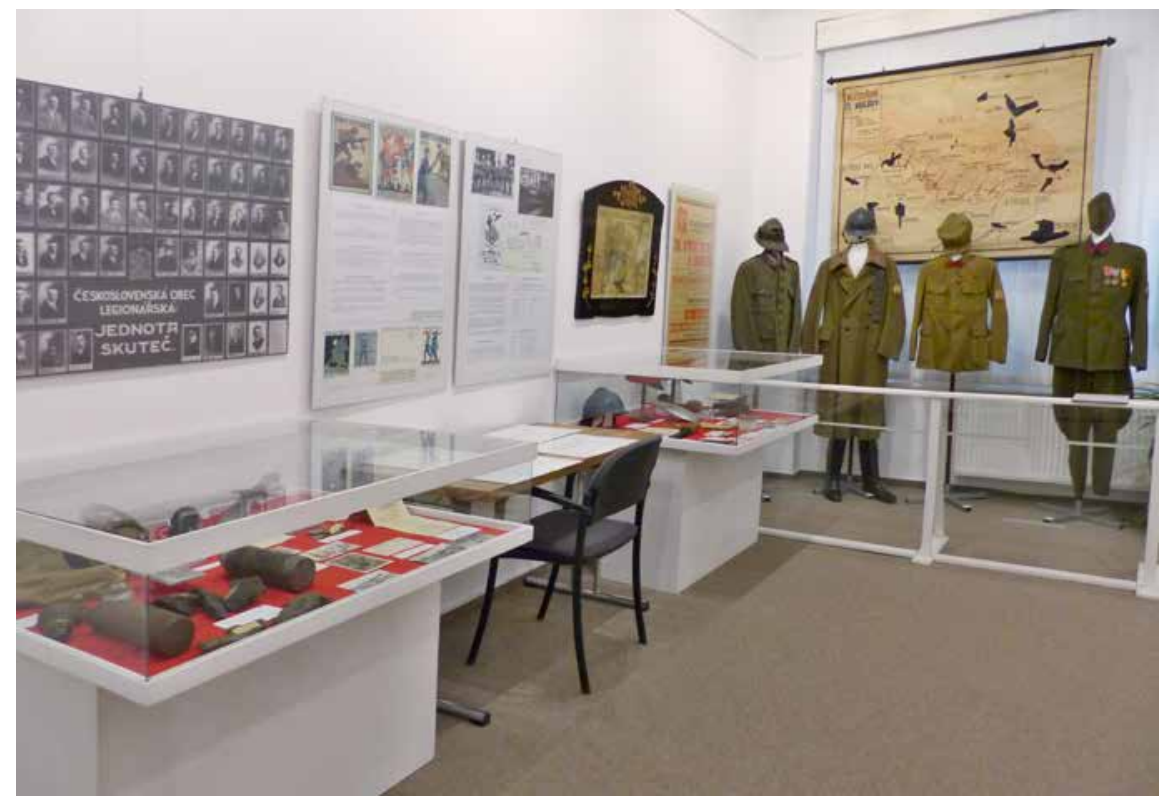

Záběr z výstavy z roku 2018. Foto archiv MM Skuteč

pohodlné listování a prohlížení obrázků, často zaujímajících celou stranu. Měkčené desky knihy navozují př́jemný pocit luxusu. Vzhled obálky se může zdát trochu roztř́štěný, ale rozhodně spolu s výstižným názvem upoutá pozornost.

\section{Kapitola 1. - Než vypukla válka}

Publikace začíná krátkým, ale důležitým základním představením města a okolí. Na omezeném prostoru se podařilo Jiřímu Junkovi přiblížit čtenáři základní body sociokulturního prostředí odvedenců, které následně přispívalo $\mathrm{k}$ formování jejich postoje a rozhodování v situacích, jako bylo např. zajetí a vstup do legií. Junek dále pokračuje popisem vývoje dvou rakousko-uherských pluků č. 30 a č. 98, do jejichž doplňovacího obvodu Skutečsko patřilo. Jimi musel projít každý zeměbranec i domobranec a $\mathrm{z}$ nich se následně rekrutovali téměř všichni zdejší legionáři. Vysoké Mýto bývalo centrem vojenské správy širokého regionu a každý muž, který dle zákona podléhal branné povinnosti, do něho dříve či později našel cestu. Díky těmto obecným úvodním informacím získá čtenář ucelený pohled na danou problematiku a následující životní příběhy skutečských vojáků je tak možné nahlédnout v širších souvislostech.

\section{Kapitola 2. a 3. - Mobilizace a Na bojištích světové války}

V druhé kapitole se již Junek věnuje vstupu Rakousko-Uherska do Velké války a procesu mobilizace. Je pozoruhodné, že doprovodné snímky z bohatého archivu vysokomýtského muzea zachycují v různých situacích právě muže, kteří pocházeli ze Skutče a okolí.

Následuje kapitola popisující fungování a pohyby vojenských útvarů, do kterých byli zdejší muži ve velkém počtu zařazeni, tj. hlavně c. a k. pěší pluk č. 98 a c. k. zeměbranecký pěší pluk č. 30. Zvláště zajímavé jsou informace o konkrétních bojových střetnutích, v nichž se muži ze Skutečska s velkou pravděpodobností nalézali. Seznamy padlých příslušníků stejné jednotky pak tyto hypotetické předpoklady potvrzují. Při studiu podkladů se dokonce podařilo najít některé dosud neprobádané dokumenty, jako např. pochvalný list o "chrabrých mužích" ze Skutče a z Vysokého Mýta, kteří se zvláště vyznamenali v bojích s Rusy. Tato informace zásadně přispívá k očištění pověsti pluku, který býval považován za národnostně nespolehlivý a pro špatnou bojovou morálku a množství dezercí byl od listopadu 1914 do února 1915 dokonce rozpuštěn.

\section{Kapitola 4. - Československé legie}

Se znalostí věci Junek, opět se zvláštním přihlédnutím $\mathrm{k}$ působení skutečských mužů, čtivě popisuje vznik a vývoj legionářských vojsk ve Francii, Rusku a Itálii. Dočteme se tak nejen obecné informace, ale také konkrétní údaje o bojovém nasazení jednotlivých pluků, kde bylo početní zastoupení skutečských největší, a to včetně elitního 1. čs. úderného praporu, kde měla Skuteč čtyři příslušníky z celkových 800 členů jednotky (!). Kapitola je vhodně doplněna přehledem nejrozšírenějších dlouhých palných zbraní používaných našimi legionáři. Detailní snímky poskytlo Východočeské muzeum v Pardubicích.

\section{Kapitola č. 5 - Válka nekončí}

Ve své závěrečné kapitole se Junek věnuje bojům s Mad’ary. Tato kapitola československých dějin není přiliš připomínána, a tak lze její popis kvitovat s povděkem. Je zde zařazena logicky, protože v bojích o hranice republiky padlo i několik mužù 


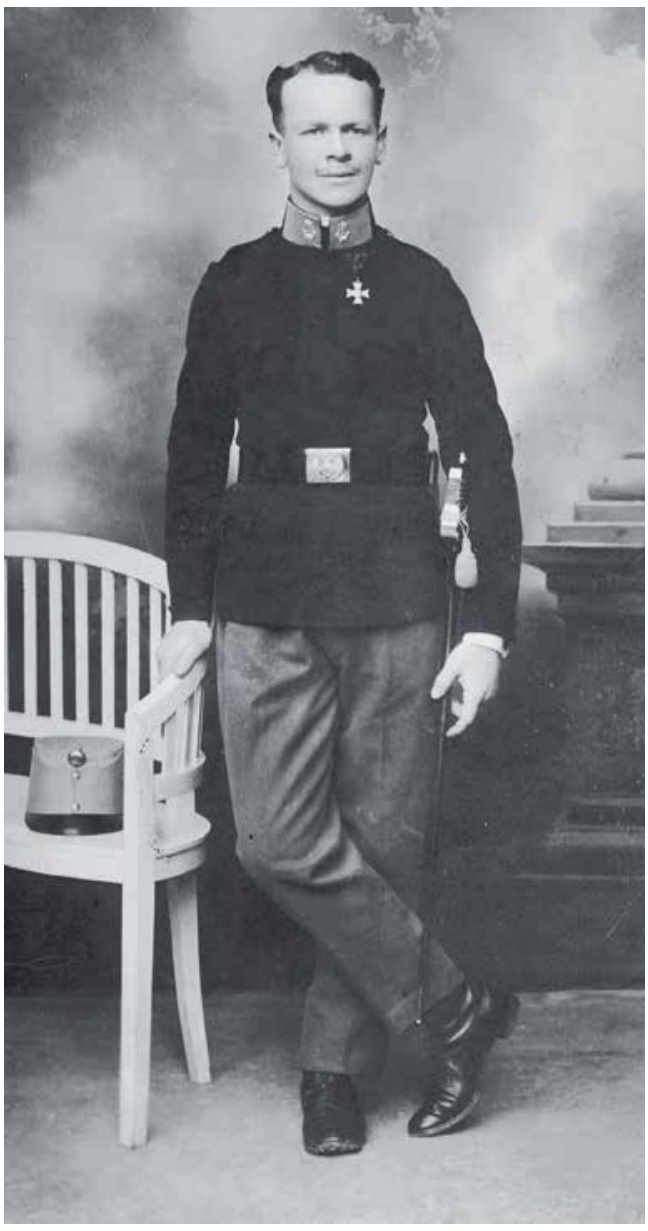

Prvním padlým ze Skutče se stal mladinký Otakar Svatoš. Foto archiv MM Skuteč

ze Skutče. Velká část kapitoly se zaobírá př́iběhem mladého poručíka Rostislava Śtěpánka. Ten se jako velitel roty útočící na nádraží ve východoslovenském Kysaku dostal do obklíčení mad’arskými vojáky. Nechtěl připustit své zajetí a raději zvolil smrt vlastní rukou. O pưl roku později byl In memoriam vyznamenán Čs. válečným křížem a stejné vyznamenání obdržel i jeho domovský II. prapor, který se tak stal prvním útvarem čs. armády s tímto oceněním.

\section{Kapitola č. 6 - Svědectví z archivu}

Touto kapitolou se slova ujímá spoluautor publikace Libor Aksler. Podkapitoly tvoři př́běhy šesti vojáků, které jsou popsány na základě studia dokumentů z několika zdrojů. Podařilo se např. lépe vytěžit muzejní sbírku archiválií, která v minulých letech prošla digitalizací a zpřesněním popisů dokumentů, což následně umožnilo cílené vyhledávání materiálů. Světlo světa tak spatřila korespondence milujícího manžela se svou ženou a malou dcerkou ukončená jeho smrtí na východní frontě. Díky nově popsanému fotoarchivu se pak povedlo najít fotografii jeho dcery jako dospělé ženy z 30. let 20. století a následně také vystopovat její potomky, dodnes žijící ve Skutči.

Další jímavý příběh se podařilo sestavit z korespondence, kterou do sbírky muzea věnoval návštěvník po prohlídce výstavy v roce 2014. Po chronologickém seřazení asi čtyř set pohlednic se počal odvíjet př́iběh lásky Františka Dušánka a jeho milé Marie Horákové. Zamilovali se do sebe krátce před vypuknutím války. Jejich vztah prošel během šestiletého odloučení těžkou zkouškou, ale nakonec skončil štastným manželstvím. Osudy dalších vojákủ bylo možné vyčíst z jejich retrospektivních vzpomínek nebo deníků, které se dochovaly bud' ve sbírce muzea, domácnostech př́buzných či ve fondech Státního okresního archivu v Chrudimi. Zdroje pro tuto kapitolu byly také čerpány mimo jiné z fondu bývalého Okresního soudu Skuteč, který řešil i pozůstalostní řízení. Ač ve fondu proběhla rozsáhlá skartace, dokumenty $\mathrm{z}$ válečného období se zachovaly a poskytují smutná a dramatická svědectví o fatálních událostech, s nimiž se musely rodiny obětí války popasovat.

\section{Kapitola 7. - Soupis padlých a zemřelých}

V úvodu sedmé kapitoly Aksler podrobně popisuje prameny a zdroje odkud informace čerpal, což jistě ocení další badatelé. Velmi zajímavé jsou souhrnné tabulky a grafy, jež nemilosrdně ukazují věkovou skladbu 202 dohledaných padlých, počty úmrtí $v$ jednotlivých letech války, přehled příčin úmrtí nebo napřs. souhrn civilního povolání vojáků. Názorná je také mapa Evropy a evropské části Ruska s označením míst, kde daný voják padl nebo byl 


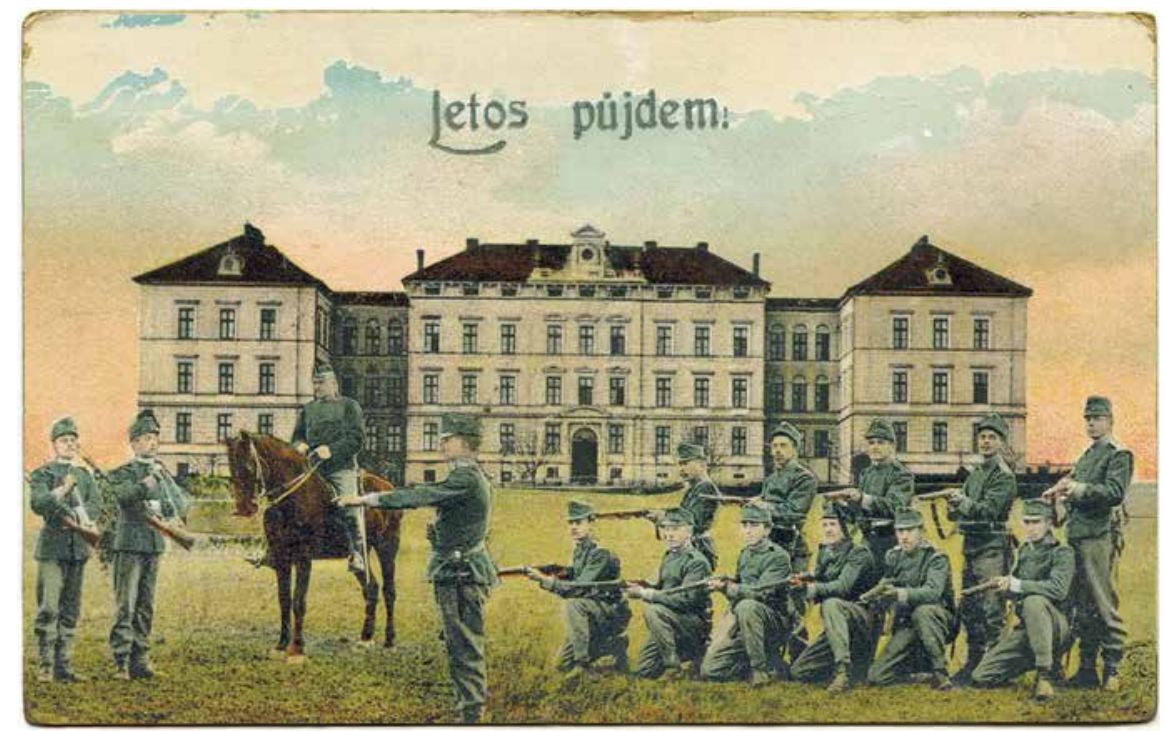

Využití našla i rada obecně dokumentačních záběrù. Foto archiv RM Vysoké Mýto

pohřben. Nad zákresem si čtenář rychle uvědomí, v jaké relativní blízkosti od domova vojáci umírali, zvláště $\mathrm{v}$ případě haličské a italské fronty. Různé typy značek jednoznačně definují i jednotlivé roky mortality.

Následující soupis padlých je rozdělen podle jednotlivých místních částí města Skutče. Muži jsou pak řazeni dle jména $\mathrm{v}$ abecedním pořadí. Údaje o každém z nich jsou vepsány do formuláře, který má pevnou strukturu. $Z$ hlediska úspory místa byly zvoleny dva sloupce a barevné rozlišení záhlaví. Velmi často jsou vkládány fotografie přímo se vztahující $\mathrm{k}$ dané osobě nebo $\mathrm{k}$ místu posledního bojového nasazení, popřípadě skeny dokumentů z osobní složky vojáka z Vojenského historického archivu, archivu skutečského muzea nebo okresního archivu v Chrudimi. Nezasvěcený čtenář se tak může setkat s celou řadou dokladů, které lze využít při vlastním bádání napr. $\mathrm{v}$ rodinné genealogii. Snad se podařilo dohledat i zcela prvního padlého skutečského vojáka, kterým se podle dosud známých dat stal Otakar Svatoš, jenž zemřel v bojích s vojáky Černé Hory 14. srpna 1914 ve věku 22 let. Do pátrání po jeho hrobě se zapojilo i místní muzeum v Risanu na pobřeží Boky Kotorské.

\section{Kapitola 8. - Seznam legionářů}

Kapitola je členěna stejně jako předchozí dle osad. Stejné zůstává i rozřazení sledovaných mužů. Jen formulář je mnohem obsáhlejší, protože se $\mathrm{k}$ vojenské činnosti $\mathrm{v}$ legiích přece jenom dochovalo více informací. Úvodní slova kapitoly patří opět specifikaci zdrojů a souhrnným tabulkám, jež sledují počty mužů $\mathrm{v}$ jednotlivých legiích, jejich zastoupení v obcích, věkové složení v době vstupu do legií nebo jejich civilní povolání. U velké části legionářu je připojena jejich podobenka, zajímavé jsou také skeny mnoha nejrůznějších dokumentů z osobních složek, které vedla Kancelár legií (dnes samostatný fond Vojenského historického archivu).

Stejně jako u předcházejícího soupisu padlých i $\mathrm{v}$ seznamu legionářu bylo datum narození každého vojáka ověřeno přímo $\mathrm{v}$ prríslušných matrikách narozených. Často tak byl odfiltrován zmatečný údaj, který do svých dokumentů nahlašovali sami vojáci. Do vzniku Čs. republiky byl každý legionář pro rakousko-uherské úřady vlastizrádcem a na jeho rodinu a majetek bývaly uvaleny těžké sankce. Proto se z opatrnosti snažili ztížit svoji identifikaci. $V$ některých případech proniklo zkomolené datum do dokumentů prostou lidskou chybou. Početná skupina osob měla dokonce několik různých těchto datací. Kromě správného data poskytly rodné matriky i jiné poznatky - např. o rodinném zázemí či povolání, správném bydlišti apod. Z oddacích matrik byly vypisovány informace o manželkách a dětech vojáků.

Překvapivě malé množství záznamů o úmrtí vojáků nalezneme $\mathrm{v}$ knihách zemřelých (skutečské) farnosti. Velkou výhodu představovala současná on-line dostupnost matrik, které jsou ve většině státních oblastních archivů již plně zdigitalizovány.

Před vlastním soupisem legionářù je ještě krátce připomenuta existence italské domobrany. Její př́slušníci neměli status legionáře, ale mnozí z nich se také zasloužili o vznik a udržení republiky, zvláště při bojích o slovenské hranice. Kromě jiného jsou $\mathrm{z}$ historie legionářù vybrány různé zajímavosti, jako např. nejstarší a nejmladší legionář, nejvyšší dosažená hodnost, př́pady, kdy si legionáři z Ruska přivezli manželky aj. Čtenář se může seznámit is př́běhy devíti bratrských dvojic a jejich rozdílným osudem $\mathrm{v}$ řadách legionářských vojsk. 


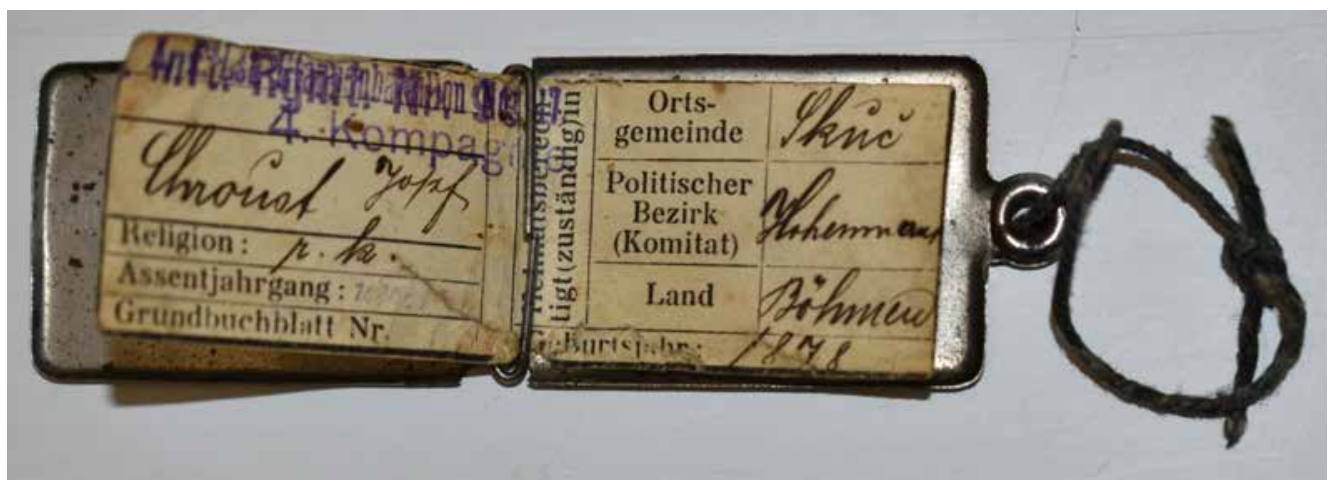

Nové údaje poskytly např. schránky s osobními údaji (obdoba dnešní vojenské známky), které muzejní sbírka dosud podrobně neevidovala. MM Skuteč, inv. č. 19.662

\section{Kapitola 9. - ČsOL - Jednota Skuteč}

Ačkoliv čítala skutečská legionářská organizace na 90 členů a založena byla velmi krátce po válce, podkladů o její činnosti se dochovalo mizivé množství. Její aktivita po pravdě nebyla nijak ohromující a bohužel i to málo, co se v agendě vedlo, zabavilo a zlikvidovalo v roce 1939 pardubické gestapo. Malý konvolut dokumentů se dochoval pouze z období, kdy docházelo k řízené likvidaci organizace ze strany komunistické vlády ČSR po roce 1948. Popis tohoto procesu však poskytuje názornou představu o atmosfére doby převratu a počátku procesu, jehož cílem bylo vymazat historii legií z paměti národa.

\section{Kapitola 10. - Vyznamenání skuteč- ských mužů}

Popis vyznamenání je rozdělen na ocenění z rakousko-uherské armády a na medaile legionářské. $\mathrm{V}$ př́ípadě vyznamenání ze starého mocnářství narazil autor na zcela nedostatečnou pramennou základnu a ledabylý popis medailí zapsaných do sbírky před mnoha desítkami let. Tehdejší nezájem o rakousko-uherské medaile a př́běhy jejich nositelů není možné napravit, informace jsou ztraceny a pamětníků již není. Více údajů se ale dochovalo $\mathrm{k}$ oceněným legionářum, a tak byl pro jejich prezentaci znovu použit formulářový styl. Rovněž jsou podrobně popsány jednotlivá vyznamenání, jež skutečští vojáci obdrželi, at již vlastní medaile jsou nebo nejsou součástí sbírky Městského muzea Skuteč.

\section{Kapitola 11. - Pamětní desky, pomniky a jejich osudy}

Poslední část publikace prezentuje veškeré připomínky 1 . světové války či legionářu ve veřejném prostoru města a jeho místních částí. S osudy některých z nich si pohrála německá okupace i následná komunistická totalita. Např. Socha Vděčnosti odhalená v červnu 1924 přišla v roce 1940 jen o nápis v kubistickém stylu, zato vzpomínková deska padlým legionářům odhalená v roce 1936 byla na základě př́kazu nacistů rozbita na prach. $\mathrm{V}$ závěru knihy je čtenář potěšen zjištěním, že i dnes se najdou instituce, které na památku padlým v 1 . světové válce neváhají pořídit

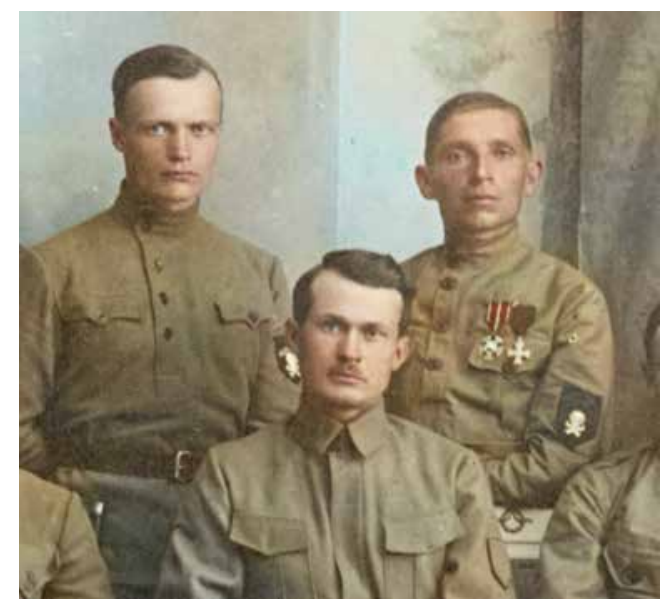

Některé snímky bylo možné pomocí počítačových programů kolorovat a zvýšit tak jejich atraktivitu pro dnešního náročného čtenáře 
a instalovat zcela novou pamětní desku. Učinilo tak město Skuteč v osadě Zbožnov $\mathrm{v}$ roce 2018.

\section{Doslov}

Závěrem lze podotknout, že ač je kniha především mikrosondou do válečného působení vojáků, kteří byli spjati se Skutčí a jejím nejbližším okolím, může poskytnout podnětné informace a zdroj poznání jednak pro nadregionální dějiny, jednak pro doplnění obecného povědomí o oblasti československé vojenské historie.

Ocenění v celorepublikové soutěži muzeí znamená velký úspěch malého muzea v kolegiálním souboji s mnohem většími institucemi, které doručily porotě celou řadu vynikajících publikací. Potěšující je, že se dlouholetý výzkum podařilo přetavit nejen do obsahově, ale i vzhledově reprezentativní knížky. Několikaměsíční náročné sestavování jednotlivých kapitol tak má na konci jednu velkou a velmi cennou tečku. A jen na okraj připomínám, že se jedná již o druhou významnou cenu skutečského muzea v Glorii musaealis (poprvé ji přebíralo v roce 2009 za otevření nové stálé expozice).

AKSLER, Libor, JUNEK, Jiří. Vojáci Skutečska 1914-1920. Skuteč: Město Skuteč, 2019. ISBN 978-80-270-7010-7 